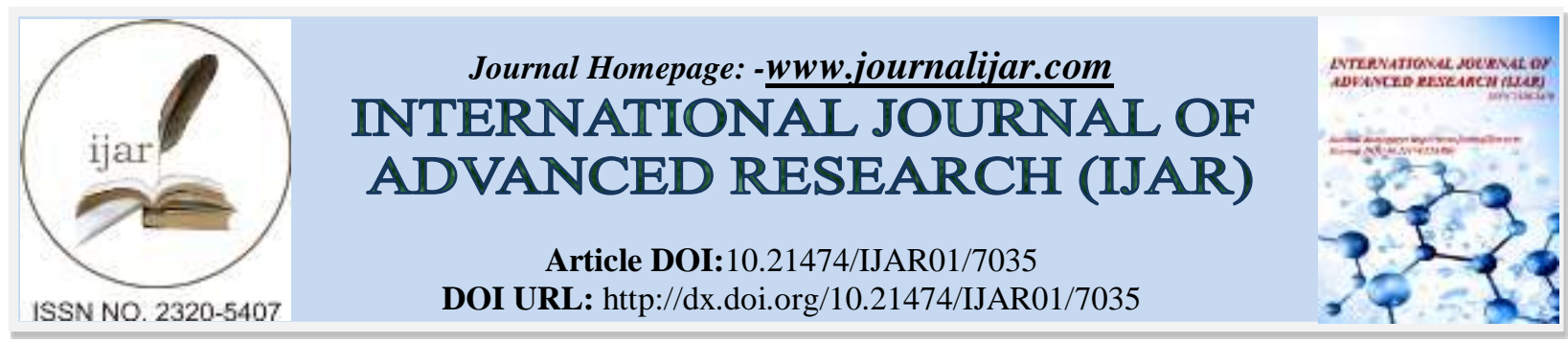

RESEARCH ARTICLE

\title{
ANALYSIS OF REGIONAL REGULATION OF WEST SULAWESI PROVINCE NUMBER 6 OF 2016 CONCERNING ESTABLISHMENT AND COMPOSITION OF STRUCTURE IN WEST SULAWESI PROVINCE
}

\author{
Aznurihsan Krisandi Azis ${ }^{1}$, Andi Pangerang Moenta ${ }^{2}$ and Hamzah Halim ${ }^{3}$. \\ 1. Graduate School, Faculty of Law, Hasanuddin University. \\ 2. Faculty of Law, Hasanuddin University. \\ 3. Faculty of Law, Hasanuddin University.
}

\section{Manuscript Info}

Manuscript History

Received: 05 March 2018

Final Accepted: 07 April 2018

Published: May 2018

Keywords:-

Composition of Structure, Establishment ,Regional Regulation, West Sulawesi Province.

\section{Abstract}

Elaboration of Government Regulation Number 18 of 2016 on Regional Devices hasn't been fully set forth in the Regional Regulation Number 6 of 2016 concerning the Establishment and Organization Structure of the Provincial Devices of West Sulawesi Province, especially in the guidance of determining the size/type of a regional device, which is also incompatible with Hierarchy of Legislation Theory proposed by Hans Kelsen. The Provincial Government of West Sulawesi doesn't fully follow the guidelines contained in Government Regulation Number 18 of 2016 on Regional Devices, due to the absence of confirmation in such arrangements that prohibits any Provincial and District/City Governments to determine the size of their regional apparatus based on recommendations issued by the Ministry of Home Affairs The Republic of Indonesia, and from the results of interviews conducted and has been described in the results of research that the determination of the scale had previously been coordinated with the Directorate General of Regional Autonomy Development Ministry of Home Affairs, so that the enactment of Regional Regulation Number 6 of 2016 on the Establishment and Organizational Structure of the Regional Government of Sulawesi West can be done. There are several factors that obstruct the overall description of the guidelines in Government Regulation Number 18 of 2016 on Regional Devices into Regional Regulation Number 6 of 2016 on the Establishment and Composition of Regional Devices of West Sulawesi Province namely Legal Factors, Facilities and Infrastructure Factors, and Cultural Factors.

Copy Right, IJAR, 2018,. All rights reserved.

\section{Introduction:-}

The state is an organization that has a purpose. The Government of the Republic of Indonesia as the organizer of this state has taken various steps in order to realize the purpose of the establishment of the Unitary State of the Republic of Indonesia as set forth in the Fourth Paragraph of the 1945 Constitution of the Republic of Indonesia which is to protect the entire nation of Indonesia and the entire blood of Indonesia, educate the nation and participate in the implementation of world order based on eternal peace and social justice. One of them in the Constitution of the

Corresponding Author:- Aznurihsan Krisandi Azis.

Address:- Jln. Perintis Kemerdekaan KM.10, Makassar, South Sulawesi, 90245, Indonesia. 
Republic of Indonesia has regulated the position and role of the people and the role of regional government in the Indonesian state administration system. ${ }^{1}$

A State Operator capable of carrying out its functions and duties solemnly and responsibly is one of the requirements to realize the purpose of the establishment of the Unitary State of the Republic of Indonesia. One form of implementation of the role of local governance in the Indonesian state administration system that is perceived by the Government in the region is the emergence of the discourse of regional autonomy with the establishment of a substitute of Law of the Republic of Indonesia Number 5 Year 1974 on the Principles of Government in the Region replaced by Republic Act Indonesia Number 22 Year 1999 regarding Regional Government as well as that has been replaced with the Law of the Republic of Indonesia Number 32 Year 2004 on Regional Government, replaced again with the Law of the Republic of Indonesia Number Year 2008 and then replaced with the Law of the Republic of Indonesia Number Year 2014 on Regional Government which has been amended several times and lastly with the Law of the Republic of Indonesia Number Year 2015.

Regional development as an integral part and national development can't be separated from the principle of regional autonomy. As an autonomous region, regions should have the authority and responsibility to organize community interests based on the principles of openness, community participation and accountability to the community. Changes to the implementation of the arrangement will of course bring significant consequences for the government as the implementer of the state. These changes will also affect the work system, payroll, facilities, budget, and work procedures, the scope of work and so on whose arrangements will be adjusted to their respective regional policies. ${ }^{2}$

One of the problems encountered in the context of local government is the institutional structure that is so fat, so it is possible the swelling in terms of budget. In addition, sometimes the existence of some institutional structures that aren't in accordance with regional needs so that the impact on the ineffective and efficient government on aspects of development. ${ }^{3}$ Departing from that matter it is very necessary to make the arrangement of regional institutions that are fully guided by the Government Regulation of the Republic of Indonesia Number 18 of 2016 About the Regional Devices.

The institutional arrangements of local government are entering into a new phase after the issuance of Government Regulation of the Republic of Indonesia Number 18 Year 2016 concerning Regional Device which is a substitute of Government Regulation Number 41 of 2007 is published by bringing significant changes to the formation of regional apparatus, with the principle of proper function and appropriate size based on workload that is in accordance with real conditions in each region. This is also in line with the principles of organizational structuring that is rational, proportional, effective and efficient. ${ }^{4}$

Type of Regional Devices contained in the Government Regulation of the Republic of Indonesia Number 18 of 2016 on the Regional Tool in Article 5, namely:

\section{Provincial Device consists of:}

1. the regional secretariat;

2. secretariat of the Regional House of Representatives;

3. inspectorate;

4. office service; and

5. entity.

\footnotetext{
${ }^{1}$ Andi Pangerang Moenta, Prinsip-Prinsip Pengaturan Sistem Otonomi Daerah dan Implementasinya di Indonesia. Spoken in the Speech Ceremony of Professorship Admission in Law Science of Law Faculty of Hasanuddin University, Monday, March 27, 2017, p. 4

${ }^{2}$ Weny Almoravid Dungga, Penataan Kelembagaan Daerah, http://rrepository.ung.ac.id/ p. 1, accessed on 17 November 2017 at 14:36.

${ }^{3}$ Weny Almoravid Dungga, Op. Cit. p. 1, accessed on 17 November 2017 at 14:36

${ }^{4}$ Pramudya, Penataan Perangkat Daerah dalam Peraturan Pemerintah Nomor 18 Tahun 2016 Tentang Perangkat Daerah.https://muhlisirfanbkn.wordpress.com/2015/01/14/pembentukan-organisasi-perangkat-daerah-dan-berbagaipermasalahan-yang-melingkupinya, accessed on November 19, 2017, at 11:22.
} 


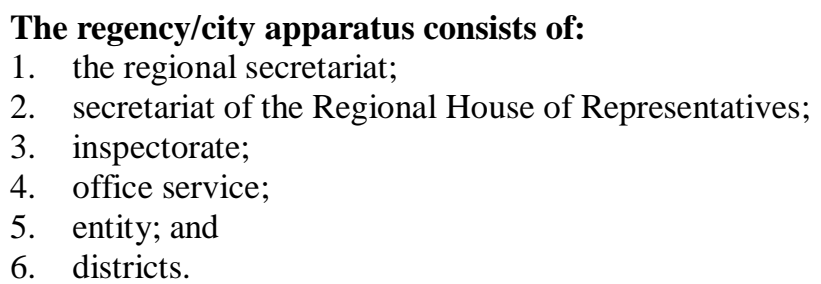

The regional apparatus to be arranged must meet the criteria of typology based on the Government Regulation of the Republic of Indonesia Number 18 of 2016 concerning the Regional Devices which will become the basis for determining the typology of a regional device with three levels of typology A, B and C, this is contained in Section Three Criteria Typology Local Government of the Republic of Indonesia Number 18 of 2016 on Regional Devices.

The establishment of regional apparatus and the composition of regional apparatus shall be stipulated by a Regional Regulation approved by the Minister of Home Affairs for the Provincial Region and the Governor for district/city. ${ }^{5}$ In the preparation of Regional Regulations on Regional Devices both Provincial and District/City Regions are expected to maximally follow the guidelines of the arrangement of regional tools contained in the Government Regulation of the Republic of Indonesia Number 18 of 2016 on the Regional Devices. However, in practice the preparation of Local Government Organizations are often constrained by political and technical factors. In practice there are political interests that accompany the determination of the establishment of a necessary institution in the region. $^{6}$ This may lead to regional non-compliance in the enactment of a Regional Regulation on the Regional Device itself. Conditions seen so far indicate that our bureaucratic institutions, including local government bureaucracies are too fat to be less agile and absorb larger budgets for themselves than spending on the public sector. $^{7}$

\section{Method of the Research:-}

This research is sociological-legal research using two legal studies namely normative and sociological or empirical legal research. According to Morris L. Cohen and Kent C. Olson (2000: 2) "The law considers of those recorded rules that society will enforce and the procedures that can implement them". If the law is seen from the juridical aspect of normative and juridical empirical then it can be classified in three categories, namely the legal science of the rules, the legal science of the aspired law, and the legal knowledge of the fact that lives in society. ${ }^{8}$

The normative juridical approach is used to analyze various legislation regulating the formation of regional device operations. While empirical juridical approach used to analyze not merely as a set of rules of law that is normatif mere, but the law seen as the behavior of society. Individual field findings will be the main ingredient in revealing the problems under study by adhering to normative requirements.

\section{Results and Discussion:-}

Elaboration of Government Regulation Number 18 of 2016 on Regional Devices into Regional Regulations of West Sulawesi Province Number 6 of 2016 on the Establishment and Composition of Regional Devices of West Sulawesi Province

Determination of the magnitude of the regional apparatus may not fulfill the rightsizing principle because the indication in the stipulation of the regional regulation does not fully refer to Government Regulation Number 18 of 2016 concerning the regional apparatus, the first will be reviewed the conformity of the principle in the regional

${ }^{5}$ Article 3 of the Government Regulation of the Republic of Indonesia Number 18 of 2016 concerning Regional Devices.

${ }^{6}$ Pramudya, Penataan Perangkat Daerah dalam Peraturan Pemerintah Nomor 18 Tahun 2016 Tentang Perangkat Daerah.https://muhlisirfanbkn.wordpress.com/2015/01/14/pembentukan-organisasi-perangkat-daerah-dan-berbagaipermasalahan-yang-melingkupinya, accessed on 19 November 2017, at 14:45 pm

${ }^{7}$ Kompasiana, 28 Juli 2016, Peraturan Pemerintah 18 Tahun 2016 Berpotensi Menggemukkan Birokrasi Pemda. https://kompasiana.com/fransdionesa/pp-18-tahun-2016-berpotensi-menggemukkan-birokrasi-pemda, accessed on November 19, 2017, at 14:52 Wita.

${ }^{8}$ A. Muktie Fajar dan Yulianto Ahmad, 2009, Dualisme Penelitian Hukum Normatif dan Empiris, Yogyakarta: Pustaka Pelajar. p. 153 
regulation with the formal principle of the formulation of legislation and the conformity of the principle between the Regional Regulation and the Government Regulation Number 18 of 2016. This Formal Principle is formulated in Article 5 of Law Number 12 Year 2011 concerning the Establishment of Legislation namely:

1. clarity of purpose;

2. institutional or proper forming authority;

3. suitability between type, hierarchy, and content material;

4. can be implemented

5. usability and usability;

6. clarity of formulation;

7. openness.

In this study, the researcher focuses on the principle of the third letter $\mathrm{c}$ of the above article namely the principle of conformity between types, hierarchy, and content material, to answer the formulation of the problems that have been raised. However, the researcher will give exposure to the above mentioned principles based on the result of research conducted on the analysis of Local Regulation Number 6 of 2016 Establishment and Composition of Regional Devices of West Sulawesi Province.

The variable value of government affairs is obtained from the mapping of the affairs based on the indicators contained in the attachment of Government Regulation Number 18 of 2016 on the Regional Devices. The indicators of mapping the affairs for education and culture as follows

Table 4.1. General Variable Indicators of Mapping Intensity of Government Affairs and Determination of Local Government Workload of Provincial Government

\begin{tabular}{|c|c|c|c|c|}
\hline Number & Indicators \& Interval Classes & $\begin{array}{l}\text { Value } \\
\text { Scale }\end{array}$ & $\begin{array}{c}\text { quality } \\
(\%)\end{array}$ & Score \\
\hline 1. & $\begin{array}{lll} & & \text { Number of Population (life): } \\
\text { a. } & \leq 2.000 .000 & \\
\text { b. } & 2.000 .001-4.000 .000 & \\
\text { c. } & 4.000 .001-6.000 .000 & \\
\text { d. } & 6.000 .001-8.000 .000 \\
\text { e. } & >8.000 .000\end{array}$ & $\begin{array}{l}200 \\
400 \\
600 \\
800 \\
1.000\end{array}$ & 10 & $\begin{array}{l}20 \\
40 \\
60 \\
80 \\
100\end{array}$ \\
\hline 2. & $\begin{array}{l}\text { An area }\left(\mathrm{Km}^{2}\right) \\
\text { a. } \leq 600 \\
\text { b. } \quad 601-1.200 \\
\text { c. } 1.201-1.800 \\
\text { d. } 1.801-2.400 \\
\text { e. }>2.400\end{array}$ & $\begin{array}{l}200 \\
400 \\
600 \\
800 \\
1.000\end{array}$ & 5 & $\begin{array}{l}10 \\
20 \\
30 \\
40 \\
50\end{array}$ \\
\hline 3. & $\begin{array}{l}\text { Amount of Regional Expenditure Budget (IDR) } \\
\text { a. } \quad \leq 2.000 .000 .000 .000 \\
\text { b. } \quad 2.000 .000 .000 .001-4.000 .000 .000 .000 \\
\text { c. } \quad 4.000 .000 .000 .001-6.000 .000 .000 .000 \\
\text { d. } \quad 6.000 .000 .000 .001-8.000 .000 .000 .000 \\
\text { e. } \quad>8.000 .000 .000 .000\end{array}$ & $\begin{array}{l}200 \\
400 \\
600 \\
800 \\
1.000\end{array}$ & 5 & $\begin{array}{l}10 \\
20 \\
30 \\
40 \\
50\end{array}$ \\
\hline
\end{tabular}

Source: Enclosure of Government Regulation number 18 of 2016

Table 4.2:-Technical Variables Governmental Affairs Education Sector Indicator Mapping Intensity Government Affairs And Determination Workload Regional Device Provincial Government

\begin{tabular}{|c|l|l|l|l|}
\hline Number & \multicolumn{1}{|c|}{ Indicators \& Interval Classes } & $\begin{array}{l}\text { Value } \\
\text { Scale }\end{array}$ & $\begin{array}{c}\text { Quality } \\
(\%)\end{array}$ & \multicolumn{1}{|c|}{ Score } \\
\hline 1. & Number of children of secondary education age & & 35 & \\
& a. $\leq 29.000$ & 200 & & 70 \\
& b. $29.001-125.000$ & 400 & & 140 \\
& c. $125.001-250.000$ & 600 & & 210 \\
& d. $250.001-375.000$ & 800 & & 280 \\
& e. $>375.000$ & 1.000 & & 350 \\
\hline
\end{tabular}




\begin{tabular}{|c|c|c|c|c|}
\hline 2. & $\begin{array}{l}\text { Number of school-age children with special needs } \\
\text { a. } \leq 700 \\
\text { b. } 701-1.401 \\
\text { c. } 1.402-3.400 \\
\text { d. } 3.401-5.400 \\
\text { e. }>5.400\end{array}$ & $\begin{array}{l}200 \\
400 \\
600 \\
800 \\
1.000 \\
\end{array}$ & 15 & $\begin{array}{l}30 \\
60 \\
90 \\
120 \\
150 \\
\end{array}$ \\
\hline 3. & $\begin{array}{l}\text { Total curriculum of local content of secondary education and } \\
\text { special education } \\
\text { a. } \leq 2 \\
\text { b. } 3-5 \\
\text { c. } \quad 6-8 \\
\text { d. } \quad 9-11 \\
\text { e. } \quad>11\end{array}$ & $\begin{array}{l}200 \\
400 \\
600 \\
800 \\
1.000\end{array}$ & 15 & $\begin{array}{l}30 \\
60 \\
90 \\
120 \\
150\end{array}$ \\
\hline 4. & $\begin{array}{l}\text { Number of secondary education units and special education held } \\
\text { by the community } \\
\text { a. } \leq 95 \\
\text { b. } \quad 96-191 \\
\text { c. } \quad 192-375 \\
\text { d. } \quad 376-500 \\
\text { e. }>500\end{array}$ & $\begin{array}{l}200 \\
400 \\
600 \\
800 \\
1.000\end{array}$ & 15 & $\begin{array}{l}30 \\
60 \\
90 \\
120 \\
150\end{array}$ \\
\hline
\end{tabular}

Source: Enclosure of Government Regulation Number 18 of 2016.

Table 4.3:-Technical Variables Government Affairs Culture Sector Indicator Mapping Intensity Government Affairs And Determination Workload Regional Device Provincial Government

\begin{tabular}{|c|c|c|c|c|}
\hline Number & Indicators \& Interval Classes & $\begin{array}{l}\text { Value } \\
\text { Scale }\end{array}$ & $\begin{array}{c}\text { Quality } \\
(\%)\end{array}$ & Score \\
\hline 1. & $\begin{array}{l}\text { The number of traditions within the province } \\
\text { a. } \leq 25 \\
\text { b. } 26-50 \\
\text { c. } 51-75 \\
\text { d. } 76-100 \\
\text { e. }>100\end{array}$ & $\begin{array}{l}200 \\
400 \\
600 \\
800 \\
1.000\end{array}$ & 50 & $\begin{array}{l}100 \\
200 \\
300 \\
400 \\
500\end{array}$ \\
\hline 2. & $\begin{array}{l}\text { Number of museums managed by the provincial government } \\
\text { a. } \leq 5 \\
\text { b. } 6-10 \\
\text { c. } 11-15 \\
\text { d. } 16-20 \\
\text { e. }>20\end{array}$ & $\begin{array}{l}200 \\
400 \\
600 \\
800 \\
1.000\end{array}$ & 10 & $\begin{array}{l}20 \\
40 \\
60 \\
80 \\
100\end{array}$ \\
\hline 3. & $\begin{array}{l}\text { The number of indigenous communities within a province } \\
\leq 25 \\
26-50 \\
51-75 \\
76-100 \\
>100\end{array}$ & $\begin{array}{l}200 \\
400 \\
600 \\
800 \\
1.000 \\
\end{array}$ & 20 & $\begin{array}{l}40 \\
80 \\
120 \\
160 \\
200 \\
\end{array}$ \\
\hline 4. & $\begin{array}{l}\text { Number of secondary education units and special education held } \\
\text { by the community } \\
\text { a. } \leq 95 \\
\text { b. } \quad 96-191 \\
\text { c. } \quad 192-375 \\
\text { d. } \quad 376-500 \\
\text { e. } \quad>500\end{array}$ & $\begin{array}{l}200 \\
400 \\
600 \\
800\end{array}$ & 15 & $\begin{array}{l}30 \\
60 \\
90 \\
120\end{array}$ \\
\hline
\end{tabular}


Source: Enclosure of Government Regulation Number 18 of 2016

To get the calculation result of intensity value of Governmental Affairs and scale of organization of Regional Government implemented with stages as follows:

Step 1: Calculates the value of each indicator of the general and technical variables by multiplying the scale of values corresponding to the actual state of the Region with a percentage of the indicator's weight.

Step 2: Calculates the sum of the values of all indicators of the general and technical variables by summing the values of all the indicators.

Step 3: To multiply the sum of values of all indicators of the general and technical variables with geographical difficulties, with the following criteria:

1. Provinces and districts in Java and Bali multiplied one;

2. Provinces and districts in Sumatra, Kalimantan, and Sulawesi and cities across the region multiplied by 1.1 ;

3. Provinces and districts in Nusa Tenggara and Maluku multiplied by 1.2;

4. Provinces and districts in Papua multiplied by 1.4;

5. Provincial and regency/municipality regions are characterized by islands multiplied by 1.4;

6. Districts in the country's border areas multiplied by 1.4; and

7. Districts/cities on the outer islands in Border Areas multiplied by 1.5 .

In the event that a Region enters into two or more classifications, the Area may choose the largest geographical difficulties factor.

Step 4:- Determination of the intensity of Government Affairs and the workload of regional apparatus based on the calculation results with the following criteria:

1. Total score less than or equal to 300 , is a very small intensity and contained in the Regional Device at the section/sub-field level;

2. Total score of more than 300 to 400 , is a very small intensity and contained in the regional level of the Device Area;

3. Total score from 401 up to 600, is a small intensity and contained in the C-type Regional Devices;

4. Total scores from 601 to 800 are of moderate intensity and contained in the Type B Regional Device;

5. Total score of more than 800 is a great intensity and is contained in a Type A Regional Device.

From the description of the attachment of Government Regulation Number 18 Year 2016 regarding the Regional Tool on how to determine the magnitude of government affairs, the mapping of Education and Cultural Affairs of the West Sulawesi Provincial Government based on Letter of the Minister of Home Affairs Number 100/2948/SJ dated August 8, 2016 regarding: Determining the Results of Mapping of Government Affairs, in Appendix I and XXII as follows:

1. For government affairs Education Division of West Sulawesi Province with a score of 825 with Large Category (Attachment I);

2. For the affairs of government Culture of West Sulawesi Province with a score of 325 with Small Category (Attachment XXII).

Based on the results of the mapping mentioned above, the Provincial Government of West Sulawesi establishes the Regional Device Organization by joining the Education and Culture Affairs set forth in the Regional Regulation Number 6 of 2016 on the Establishment and Composition of the Regional Devices of West Sulawesi Province in Article 4 letter d point 1, that: "Provincial Education and Culture Office Type A organizes government affairs in Education and Culture"

\begin{tabular}{l|l|l|l|l|}
\hline 4. & Number of administrators of population administration information & & 10 \\
& system in districts/cities integrated with provinces & 200 & 20 \\
a. $\leq 50$ & 400 & 40 \\
b. $51-100$ & 600 & 60 \\
c. $101-150$ & 800 & 80 \\
d. $151-200$ & & \\
\hline
\end{tabular}


e. $>200$

1.000

100

Source: Enclosure of Government Regulation Number 18 of 2016

Referring to Letter of the Minister of Home Affairs Number 100/2948/SJ, dated August 8, 2016, concerning: Recommendation on the Establishment of Government Mapping Results, in Appendix XII Outcome of Intensity Mapping and Working Burden of City/The Administration of Population and Civil Registration of the Provincial Government of West Sulawesi scored 517 with the Small category. The results obtained herein, when referring to the Guidelines stipulated in Government Regulation Number 18 of 2016 on Regional Devices, Population and Recording Agencies that can be formed in the Province of West Sulawesi with C typology.

Based on the above mapping, the Provincial Government of West Sulawesi establishes the Regional Device on Demographic and Civil Registration which has been stipulated in Regional Regulation Number 6 of 2016 concerning the Establishment and Composition of Regional Devices of West Sulawesi Province in Article 4 letter d point 10, that: "Provincial Population and Civil Registration Office Type B holds government affairs in the field of population and civil registration"

According to the authors, the determination of the size of the Department of Population and Civil Registration in the Provincial Government of West Sulawesi is not guided by the Mapping Results and Intensity of Provincial and Regency/City Government Affairs All of Indonesia which according to also directly not guided by the rules or norms stipulated in Government Regulation Number 18 Article 201 of the following article 53 attaches. This shows that the West Sulawesi Provincial Government doesn't follow the principle of suitability of species, hierarchy and content material that has referred to the above rules/regulations, and this also is not in line with the Hierarchy Theory.

The results of mapping of intensity and workload for supporting functions aren't contained in the Letter of the Minister of Home Affairs Number 100/2948/SJ, dated August 8, 2016, regarding: Recommendation of Determination of Government Affairs Mapping Results, but research in the field of researchers obtained data mapping validation results signed by the Ministry of Home Affairs Representative, Head of Bureau of Organization and Management of the Regional Secretariat of West Sulawesi Province and Representative of the Regional Device Working Unit dealing with Finance (attached). The final score of the mapping results is 627, based on the scores based on qualifications contained in Article 53 of Government Regulation 18 of 2016 on the Regional Devices then for the Supporting Functions of West Sulawesi Provincial Government is included in the Agency with Medium Category.

Viewing the mapping results through validation data for the financial support function of West Sulawesi Provincial Government with Medium Category, the regional apparatus organization that handles the financial support function that can be established in West Provincial Government is a B-shaped Agency. In Regional Regulation Number 6 Year 2016 regarding Formation and Composition of Regional Devices of West Sulawesi Province in Article 4 letter e number 2, that: "Provincial Finance Board Type A holds government affairs in the Finance field"

According to the researcher, the determination of regional apparatus organization that performs financial support function at West Sulawesi Provincial Government, ie Western Province Regional Finance Agency with Type A, is not in accordance with the guideline set forth in Government Regulation Number 18 Year 2016 on Regional Device and its attachment. This indicates that the Provincial Government of West Sulawesi in the enactment of Regional Regulation Number 6 of 2016 on the Establishment and Composition of the Regional Devices of West Sulawesi Province does not follow the principle of conformity of species, hierarchy and content material that has been referring to the provisions / regulations on it, and this is also not in line with Hierarchical Theory.

Factors inhibiting the elaboration of Government Regulation of the Republic of Indonesia Number 18 of 2016 in West Sulawesi Provincial Regulation Number 6 of 2016 on the Establishment and Composition of Regional Devices of West Sulawesi Province 
The discussion on the results of this study, focusing on Factors affecting the law according to Soerjono Soekanto are: $^{9}$ 1) Factor of law/legal substance; 2) Facilities and infrastructure; and 3) Culture, which inhibits the elaboration of all guidelines contained in Government Regulation Number 18 of 2016 on Regional Devices into Local Regulation number 6 of 2016 on the Establishment and Composition of Regional Devices of West Sulawesi Province. Where in the discussion of the results of previous research and discussion has been described several things in Government Regulation Number 18 of 2016 which is not spelled out into Regional Regulation Number 6 of 2016.

Factor Legal/legal substance:-

The legal substance which is the obstacle in this research is the legal substance in the Regional Regulation Number 6 of 2016 concerning the Establishment and Composition of Regional Devices of West Sulawesi Province which doesn't fully describe the guidance of determination of typology of local instruments contained in Government Regulation Number 18 Year 2016 on Device Area. These are some points in Article 4 of Regional Regulation Number 6 of 2016 concerning the Establishment and Composition of Regional Devices of West Sulawesi Province which covers Provincial Government Affairs of Population and Civil Registration, Provincial Government Affairs for Community Empowerment and Village Empowerment and Government Affairs Support for Finance.

According to the authors, the determination of the magnitude of the Organization of Regional Devices which organizes the Government Affairs for the Empowerment of Communities and Villages in this case the Department of Community Empowerment and Villages of West Sulawesi Province is not guided by the Result of Mapping of Intensity and Workload of City/Attachment XII of the Letter of the Minister of Home Affairs Number 100/2948/SJ dated August 8, 2016, regarding: Recommendations for the Establishment of the Result of Mapping of Government Affairs, which is also not guided by the provisions in Government Regulation Number 18 Year 2016 Article 53 hereinafter annexes.

This condition indicates the substance of the Regional Regulation becomes a less effective point according to the theory of legal effectiveness based on the legal factor/substance of the law itself, causing the swelling of structures within the organization. This can be seen when referring to the Mapping Results of Provincial Government Affairs with the Office of the Typology C as contained in Article 63 of Government Regulation Number 18 of 2016 on the Regional Device that:

1. The Provincial Service of type C consists of one secretariat and at most two fields.

2. The Secretariat as referred to in paragraph (1) shall consist of 2 (two) subsections.

3. Field referred to in paragraph (1) shall consist of at most 3 (three) sections."

\section{Supporting Facilities and Infrastructure Factors:-}

Supporting facilities and infrastructure factors that inhibit the elaboration of Government Regulation Number 18 of 2016 on Regional Devices into Regional Regulation Number 6 of 2016 on the Establishment and Composition of Regional Devices of West Sulawesi Province, researchers try to get by conducting direct interviews at the Regional Organization \& Management Bureau of Provincial Region West Sulawesi which is the leading sector of the formation of this Regional Regulation. From the interview result, it is found that in the Budget Implementation Document and Document of Implementation of Budget Changes of Fiscal Year 2016 at the Organization \& Management Bureau there is no special activity regarding the formation of the Regional Regulation, this is stated by Masriadi Nadi Atjo, as Head of Organization \& that: "In the implementation of the preparation of this Regulation of Regional Regions, there is no provision for the preparation of the Regional Regulation, it is only implemented because it is an order in the Government Regulation Number 18 of 2016 on Regional Devices with the deadline no later than December 2016, while the Government Regulation is legalized in June 2016 where the condition of the Budget Implementation Document 2016 Fiscal Year has been established and has been running, in the period of budget changes has been proposed additional activities, but because the conditions at the time of change Amount of all regional budget Tool is actually rationalized/minus, specifically at the Bureau of Organizational Organizations around one billion rupiah reduced"

\footnotetext{
${ }^{9}$ Soerjono Soekanto, 2004, Faktor-Faktor Yang Mempengaruhi Penegakan Hukum, Cetakan Kelima, Jakarta : Raja Grafindo Persada, p. 42
} 


\section{Factors Culture:-}

Culture according to Soerjono Soekanto, has a very big function for people and society, which is set so that people can understand how should act, do, and determine their attitude if they relate to others. Culture, then, is a fundamental line of conduct that establishes rules about what to do and what is forbidden. ${ }^{10}$

Culture Society in this study is a civil State Apparatus culture civil society scope of West Sulawesi Province, to determine the cultural factors that inhibit the elaboration of Government Regulation Number 18 of 2016 on the Regional Device into Regional Regulation Number 6 of 2016 on the Establishment and Composition of Regional Devices Sulawesi West, researchers conducted direct interviews with Ismail Zainuddin, as the Regional Secretary of West Sulawesi Province.

\section{Conclusions:-}

Elaboration of Government Regulation Number 18 of 2016 on Regional Devices hasn't been fully set forth in the Regional Regulation Number 6 of 2016 concerning the Establishment and Organization Structure of the Provincial Devices of West Sulawesi Province, especially in the guidance of determining the size/type of a regional device, which is also incompatible with Hierarchy of Legislation Theory proposed by Hans Kelsen. The Provincial Government of West Sulawesi doesn't fully follow the guidelines contained in Government Regulation Number 18 of 2016 on Regional Devices, due to the absence of confirmation in such arrangements that prohibits any Provincial and District/City Governments to determine the size of their regional apparatus based on recommendations issued by the Ministry of Home Affairs The Republic of Indonesia, and from the results of interviews conducted and has been described in the results of research that the determination of the scale had previously been coordinated with the Directorate General of Regional Autonomy Development Ministry of Home Affairs, so that the enactment of Regional Regulation Number 6 of 2016 on the Establishment and Organizational Structure of the Regional Government of Sulawesi West can be done;

There are several factors that obstruct the overall description of the guidelines in Government Regulation Number 18 of 2016 on Regional Devices into Regional Regulation Number 6 of 2016 on the Establishment and Composition of Regional Devices of West Sulawesi Province, among others, Factor of Law itself, Facilities and Infrastructure, Cultural Factors.

\section{References:-}

1. A. Muktie Fajar dan Yulianto Ahmad, 2009, Dualisme Penelitian Hukum Normatif dan Empiris, Yogyakarta: Pustaka Pelajar.

2. Achmad Ruslan, 2013, Teori dan Praktik Pembentukan Peraturan Perundang-Undangan di Indonesia, Yogyakarta: Rangkang Educatiion

3. Andi Pangerang Moenta, Prinsip-Prinsip Pengaturan Sistem Otonomi Daerah dan Implementasinya di Indonesia. Spoken in the Speech Ceremony of Professorship Admission in Law Science of Law Faculty of Hasanuddin University, Monday, March 27, 2017.

4. Bagir Manan, 1990, Hubungan antara Pusat dan Daerah Berdasarkan Asas Desentralisasi Menurut UUD 1945, Disertasi Doktor dalam Hukum Tata Negara, Fakultaas Pasca Sarjana Universitas Padjadjaran, Bandung

5. Hamzah Halim dan Kemal Redindo Syahrul Putra, 2009, Cara Praktis Menyusun \& Merancang Peraturan Daerah (Suatu Kajian Teoretis \& Praktis Disertai Manual) Konsepsi Teoretis Menuju Artikulasi Empiris, Jakarta: Kencana

6. Jimly Asshiddiqie, 2006, Perkembangan dan Konsolidasi Lembaga Negara Pasca Reformasi. Cet. Kedua, Jakarta: Setjen dan Kepaniteraan MK RI

7. Josef Mario Monteiro, 2016, Hukum Pemerintahan Daerah, Jakarta: Pustaka Yustisia

8. Moh. Mahfud MD, 2014, Politik Hukum di Indonesia, Jakarta : Rajawali Pers

9. Mukti Fajar ND dan Yulianto Achmad. 2010, Dualisme Penelitian Hukum Normatif dan Hukum Empiris, Yogyakarta: Pustaka Pelajar

10. M. Solly Lubis,1989, Serba-Serbi Politik Hukum, Bandung: Mandar Maju

11. Peter Mahmud Marzuki, 2008, Penelitian Hukum, Jakarta: Kencana

12. Prajudi Atmosudirdjo, 1999. Teori Organisasi, Cet. II, Jakarta: STIA-LAN

${ }^{10}$ Ibid., 
13. Pramudya, Penataan Perangkat Daerah dalam Peraturan Pemerintah Nomor 18 Tahun 2016 Tentang PerangkatDaerah.https://muhlisirfanbkn.wordpress.com/2015/01/14/pembentukan-organisasi-perangkatdaerah-dan-berbagai-permasalahan-yang-melingkupinya

14. Soerjono Soekanto, 2004, Faktor-Faktor Yang Mempengaruhi Penegeakan Hukum, Cetakan Kelima, Jakarta: Raja Grafindo Persada.

15. Weny Almoravid Dungga, Penataan Kelembagaan Daerah, http://rrepository.ung.ac.id/ 